\title{
INDIVIDUAL SECESSION AND EXTRATERRITORIALITY
}

\author{
JOAKIM KÄMPE*
}

Fecha de recepción: 5 de septiembre de 2012.

Fecha de aceptación: 19 de diciembre de 2012.

Resumen: El propósito de este ensayo consiste en tomar la observación de Mises acerca de la necesidad de aceptar el derecho de secesión si se pretende hacer del programa liberal de paz y responsabilidad una realidad, y eliminar las dudas por él expresadas en relación a la posibilidad de extender tal derecho al individuo. Llevamos a cabo dicha tarea por medio de la explicación de los fundamentos teóricos e históricos del concepto de extraterritorialidad y mostrando cómo la extraterritorialidad (o mejor aún, la no territorialidad) es el único sistema coherente con los derechos individuales, la propiedad privada y el principio de no agresión. Al permitir la secesión individual nuestra propuesta plantea un sistema altamente descentralizado, dinámicamente eficiente, competitivo, voluntario y en constante evolución, que además podría dar lugar a una creciente diversificación de los códigos legales de acuerdo a los deseos subjetivos de los individuos.

Palabras clave: Extraterritorialidad, Secesión, Autodeterminación, Praxeología.

Clasificación JEL: A10, A12, K00, K10, N40.

Abstract: The purpose of this paper is to take Mises' observation on the need for the right of secession in order for the liberal program for peace and prosperity to be realized, and remove the doubts that he voiced regarding the feasibility of extending this right to individuals. We do so by explicating the theoretical and historical foundation of the concept of extraterritoriality, and by showing how extra-, or non-, territoriality is the only system which is consistent with individual rights, private property, and the non-aggression

* Ludwig von Mises Institute Sweden. Vinodlargatan 2, 11857 Stockholm, Sweden Tel: +46708965019.

I owe a great deal of gratitude to Richard C.B. Johnsson and Celia Cobo-Losey for opening my eyes to the principle of extraterritoriality. I would also like to thank Phillip Bagus, who was the director of my master thesis, and Jesús Huerta de Soto. 
principle. By allowing for individual secession our proposal represents a highly decentralized, dynamically efficient, competitive, voluntary and constantly evolving system, and it would allow for an increasing diversification of law codes fully consistent with people's subjective wishes.

Key words: Extra-territoriality, Secession, Self-determination, Praxeology.

JEL Classification: A10, A12, K00, K10, N40.

I

\section{INTRODUCTION}

In this paper I set out to show that the right of secession, in order to be logically consistent with individual rights, self-determination, and the non-aggression principle, needs to allow for secession down to the individual level. The Austrian economist Ludwig von Mises recognized this necessity in his 1927 book Liberalism yet stopped short of advocating individual secession because of "compelling technical considerations.» It is the aim of this paper to show that they can be resolved by a legal principle called Extraterritoriality, or even better, Non-Territorial Governance. Under territoriality the laws follow the land. In contrast, under a system of Extraterritoriality or Non-Territorial Governance, the laws instead follow the person. Once we apply this principle, Mises' considerations are shown to be void and we are once again in a position to, along fully Misesian lines, promote secession down to the individual level in a way that is fully consistent with individual rights, private property and the non-aggression principle.

\section{II}

\section{THE STATE, TERRITORIAL GOVERNANCE AND SECESSION}

Before we start our discussion we need to clarify some basic concepts first, and what better place to start than with the concept «state» as defined by the German sociologist Max Weber who pointed out that 
... a state [...] claims the monopoly of the legitimate use of physical force within a given territory. Note that «territory» is one of the characteristics of the state. ${ }^{1}$

As Weber correctly points out, the state is closely linked with the territory over which it rules. The concept of territory means that the state has an absolute and exclusive jurisdiction over the land within its borders. Anyone within the borders of a nation state must yield and be subject to the «law of the land,,$^{2}$ citizens and non-citizens alike. ${ }^{3}$ Thus when we speak of Swedish or Spanish law, we are talking about the law as it is applied on any territory that belongs to the Swedish or Spanish government/state and not how it is applied to Swedish or Spanish citizens. It is the territory where an action is committed that determines whether or not a crime, or even what sort of crime, has been committed. Further, once a crime is found to have been committed, it is the territory where the crime was committed that determines the competent court for the case. Thus, for instance, a Spanish citizen that commits a crime on Swedish territory, regardless of the victim's citizenship, is to be judged in a Swedish court according to Swedish law. ${ }^{4}$

This system of governance can best be called territorial governance.

Territorial governance can exist in many different forms. A territory can be divided into more or less autonomous regions or areas, there can be tax free/free trade zones, and so on. Yet the common feature is that the laws and regulations, law enforcement, and court systems are exclusively bound to the territory that

\footnotetext{
1 Weber (1919), p. 1.

${ }^{2}$ For instance, we can find the principle of the Law of the Land stated as early as in 1297, in the Magna Carta:

No Freeman shall be taken or imprisoned, or be disseised of his Freehold, or Liberties, or free Customs, or be outlawed, or exiled, or any other wise destroyed; nor will We not pass upon him, nor condemn him, but by lawful judgment of his Peers, or by the Law of the Land.

3 This is generally the case, although there are exceptions. Such as for instance monarchs and diplomats.

${ }_{4}^{4}$ There are some exceptions to this general principle. Yet these exceptions are to be seen as a departure from territorial governance to a non-territorial, personal, governance. More on that later, see Chapter IV.
} 
the governing body, or the administrative unit, be it a local semiautonomous government or a central government, administers. Each administrative unit has a set of laws and regulations that applies on its territory. Semi-autonomous territories might have absolute and exclusive jurisdiction over the territory on some issues, but never on all issues.

The territory of a state can either increase, as is the case when a state conquers or annexes a territory, or decrease, as is the case when a piece of the territory is conquered or secedes from the larger, territorial, political unit and creates its own political unit or joins another political unit. It is with the latter concept, i.e. the concept of secession, which we will deal with in this paper.

The usage of the word secession in a political sense is actually quite recent and closely linked with the American Revolutionary War. As Donald W. Livingston writes,

The English verb «to secede» comes from the Latin «secedere,» meaning any act of withdrawal. The exclusively political connotations that govern the term today are peculiarly American, and do not appear in English until the early nineteenth century. [footnote omitted] [...] One of the first to use the term in this new and exclusively political way was Thomas Jefferson, who, in 1825, retrospectively described the colonies as having seceded from the British Union. ${ }^{5}$

Secession under territorial governance essentially means that parts of the territory «break free» and create their own, selfgoverning and sovereign, administrative unit. This new administrative unit is also tied to the territory over which it rules, and it differs from the previously mentioned semi-autonomous governments in that it now claims absolute and exclusive jurisdiction over the specific territories regarding all issues. This means that, at least, this newly founded administrative unit will have its own laws, law enforcement, a court system, and so on, effective within its borders.

History is full of examples of secessions, both peaceful, such as when Slovakia seceded from the Czech Republic, and violent, the

\footnotetext{
${ }^{5}$ Gordon (1998), p. 1.
} 
most famous example being the American Revolutionary War, but also more recently in the 1990s with the break-up of Yugoslavia.

\section{III \\ THE NECESSITY AND NEED FOR INDIVIDUAL SELF-DETERMINATION}

As was seen in the previous section, secession has most often, we might even say almost exclusively, been thought of in territorially collective terms, as territorial groups with some commonality breaking free from other territorial groups with another commonality. This commonality can be related to language, race, religion, etc. The idea behind the modern theory of the nationstate is that every linguistic group (i.e. nation) ${ }^{6}$ has the right to self-determination, of having its own government. This is often referred to as the self-determination of nations. However, this creates obvious problems in territories where mixed nationalities live side by side, which is evidenced by the numerous nationalistically fueled conflicts throughout history.

In his 1927 book Liberalism, the Austrian economist and classical liberal Ludwig von Mises set out to solve this problem, and to make the case for the liberal ${ }^{7}$ social order. In a particularly striking passage Mises concludes that if peace and prosperity are to be achieved the right to self-determination, or secession, necessarily has to be granted. Only by granting this could revolutions and civil as well as international wars be prevented. He stated,

The right of self-determination in regard to the question of membership in a state thus means: whenever the inhabitants of a particular territory, whether it be a single village, a whole district, or a series of adjacent districts, make it known, by a freely conducted plebiscite, that they no longer wish to remain united to the state to which they belong at the time, but wish either to

\footnotetext{
6 See Mises (1919), pp. 38-39.

7 The word liberal is henceforth used in the Classical sense and not the American sense (which has come to be more or less synonymous with Socialism or Leftism), unless otherwise noted.
} 
form an independent state or to attach themselves to some other state, their wishes are to be respected and complied with. This is the only feasible and effective way of preventing revolutions and civil and international wars. ${ }^{8}$

Indeed, Mises even maintains that this right of self-determination is the only one that is consistent with individual rights when he stated that,

the principle of the right of self-determination [...] follows necessarily from the principle of the rights of man. [footnote omitted] No people and no part of a people shall be held against its will in a political association that it does not want. ${ }^{9}$

It is clear that Mises is referring to the right to secede, that is, the right of groups of people to get together and secede from a larger administrative and territorial unit, either by forming their own administrative and territorial unit or by joining themselves to another. That Mises views regarding self-determination stayed more or less the same up until his death in 1973 is evidenced by the fact that he made a similar point in what came to be his last book, The Ultimate Foundation of Economic Science, in 1962, where he wrote that,

when every territory can by majority vote determine whether it should form an independent state or a part of a larger state, there will no longer be wars to conquer more provinces. ${ }^{10}$

Controversial as the idea of secession ${ }^{11}$ at first might be for some, it is simply nothing but the principle of freedom of association, this liberal principle which almost everyone seems to accept without hesitation, ${ }^{12}$ taken to its logical conclusion. After all,

8 Mises (1927), p. 109.

${ }_{9}^{9}$ Mises (1919), p. 60.

10 Mises (1962), p. 93.

11 For some literature that deals with secession from a libertarian point of view see Gordon (1998) as well as Hoppe (2003).

12 Indeed, the Freedom of Association is even in the UN Human Rights Charter, and while I don't necessarily put much weight to what the UN says it is nonetheless curious that the large majority of people accept the freedom of association without hesitation but at the same time generally, almost exclusively, deny such implied rights 
one is only free to associate if one is also free not to associate (to dis-associate). Were one not free not to associate, but instead forced into associations against one's will, as well as being forced to stay in associations one no longer wishes to be part of, we would in fact no longer be talking about the freedom to associate but rather the obligation to associate. Only in a deeply confused and muddled mind could such an obligation be called a freedom.

Now, it is clear that Mises' point, when he talks about the right to self-determination, is that only if people are truly free to associate and dis-associate as they see fit, only if they are never forced into associations that they do not want to be a part of, can peace be achieved and conflicts avoided. Mises writes,

The idea of liberalism starts with the freedom of the individual; it rejects all rule of some persons over others; it knows no master peoples and no subject peoples, just as within the nation itself it distinguishes between no masters and no serfs. [...] He who [...] rejects the rule of some over others and demands the full right of self-determination for individuals and peoples has thereby rejected war also. [...] If one wants to make peace, then one must get rid of the possibility of conflicts between peoples. ${ }^{13}$

However, unfortunately Mises' rather naïve views regarding democracy create somewhat of a dilemma that for anyone committed to individual rights and the non-aggression principle at first might seem hard to solve.

The majority vote that Mises is referring to in reality does not get rid of the possibility of conflict at all, and neither is it consistent with the principle of freedom of association. Rather the very opposite is true, and it is not hard to grasp why it is so. ${ }^{14}$ After all, if $51 \%$ of the voting public ${ }^{15}$ wants a territory to belong to State

as secession or even discrimination, which both simply are the most obvious cases of the freedom not to associate. You cannot have freedom of association without the freedom not to associate, since if you are not allowed not to associate, we are not talking about a freedom to associate, but an obligation.

13 Mises (1919), p. 107.

14 For further reading on this see Hoppe (2000), Karsten and Beckman (2011), and Smith (1989).

15 And one might also ask the question just exactly what constitutes «the voting public»? Anyone over 18 years of age? Sure, but what about the 17 year olds. Or the 
A and not to State B, and the remaining $49 \%$ wants the territory to belong to State B and not to State A, the will of the majority will in this case overrule the will of the minority. The majority will clearly force the minority to be a part of an association they do not want to be a part of. The will (and association) of the majority will be forced upon the minority. Clearly this is in no way conflict reducing.

Only in the rather unlikely case that the inhabitants that want to belong to State A are completely geographically separated from the inhabitants that want to belong to State B can this question be solved by giving both groups the right to form their own separate territories under the state of their choice. ${ }^{16}$ If, which is far more likely, the people that want to belong to State A and the people that want to belong to State B live mixed on the same territory, the will (and association) of the majority will quite obviously be imposed on the minority, which of course is bound to create conflict. ${ }^{17}$

Indeed, democratic votes of this kind are never about what the individual wants to happen to himself or what «the inhabitants» want for «themselves», but rather what the individual voter wants to happen to everyone else. Unfortunately, using collective concepts such as «the inhabitants» or "the people» might cloud this simple fact. The only way to get out of this dilemma would be if the will of all individuals were respected. Only in this case would no one be forced to accept anyone else's way of life, and no one would be allowed to force their way of life on anyone else. Indeed, this is what the liberal program for peace and prosperity taken to its logical conclusion would be.

16 year olds. Etc. Just as Hoppe (2000), and Karsten and Beckman (2011), have pointed out, democracy in itself leads to and promotes conflict.

${ }^{16}$ However, what if there are some people, even just one, in one of these territories that disagrees with the rest? That of course just brings us back to the original problem.

17 In Nation, State and Economy Mises reasons that in any territory where there is a minority nation, democracy would not work for them since under democracy they would inevitably be found to be in the minority and thus be without any real political rights (since they would not be able to rise to power). Mises, (1919), pp. 7374. It is hard to understand why this argument would not apply to individuals, and non-linguistic groups of individuals, as well. After all, as Ayn Rand correctly and poignantly pointed out, the smallest minority on earth is the individual. Rand (1966). 
Moreover, Mises unfortunately resorts to a collectivist reasoning when he states that when the inhabitants of a particular territory no longer want to belong to a specific state but wish to attach themselves to another state or create their own state, their wishes are to be respected and complied with. This is clearly in contradiction to what Mises has written elsewhere, and it is a clear abandonment of his own methodological individualism. As Mises puts it, in perfectly clear language, in Socialism:

All rational action is in the first place individual action. Only the individual thinks. Only the individual reasons. Only the individual acts. ${ }^{18}$

It is hard to square this argument with Mises' statement that it is the inhabitants that decide, and that it is the wish of the inhabitants that is to be respected and complied with. But inhabitants do not and indeed cannot act, think, want, wish or feel. These concepts are only applicable to individuals.

Further, either «inhabitants» in this case refers to everyone $(100 \%)$, in which case it is actually the wishes, wants and actions of all the separately existing individuals, and not the collective concept «inhabitants», that is to be respected and complied with. Or «inhabitants» does not refer to everyone but only to the majority $(>50 \%)$. Ok, so be it, but what then of the minority? What exactly are they if they are not inhabitants?

Now, Mises does seem to understand this point, and he makes it clear that when he speaks about self-determination he, albeit only in principle, is referring to actual individuals being allowed the right to self-determination. Indeed, he goes as far as to say that it would have to be done if it were in any way possible. He states,

However, the right of self-determination of which we speak is not the right of self-determination of nations, but rather the right of self-determination of the inhabitants of every territory large enough to form an independent administrative unit. If it were in any way possible to grant this right of self-determination to

18 Mises (1962), p. 113. 
every individual person, it would have to be done. This is impracticable only because of compelling technical considerations, which make it necessary that a region be governed as a single administrative unit and that the right of self-determination be restricted to the will of the majority of the inhabitants of areas large enough to count as territorial units in the administration of the country. ${ }^{19}$

What is truly remarkable about the preceding passage is that Mises in principle, and contrary to how secession is, and generally has been, viewed, sees the necessity of viewing secession in an individual light instead of the previously mentioned collective one. He expressly points out that he is not talking about the selfdetermination of nations, but rather the right to self-determination for every individual person.

This right of self-determination on an individual level (individual secession) means that individuals would have the right to secede from the larger unit and be either unattached or join another unit. Mises' recognition that the right of self-determination would have to be given to every individual is in reality almost synonymous with anarcho-capitalism. ${ }^{20}$ Nevertheless, Mises falls short of advocating pure anarchism by stating that it is not possible to grant individuals the right to self-determination because of compelling technical considerations.

But what exactly are these technical considerations?

The problem is to be found in territoriality. As we saw earlier, the concept of secession under territorial governance means that the seceding territories form their own administrative units,

19 Mises (1927), pp. 109-110.

20 It is often maintained that Mises in fact was not an anarchist and that he had nothing but contempt for anarchists. They quote a famous passage from Mises where he calls the anarchist view hopelessly naïve. Two things must be noted. First of all, upon reading Mises it is clear that the anarchism he rejects is of the leftist variety and not of the capitalist type typical of Murray Rothbard. Second, while it is true that Mises never called himself an anarchist, and stops short of promoting individual secession, his position is more or less as close to anarchism as you can come without actually arriving. See on this Rothbard (1981). For more on the theory of anarchocapitalism see Molinari (1849), Rothbard (1982), Rothbard(1973), and Hoppe (2000), as well as Hoppe (1988). 
in territories over which they claim absolute and exclusive jurisdiction on all issues. These newly created administrative units would be, at least, responsible for laws, law enforcement, a court system, repelling trespassers and aggressors, and so on.

Now, since Mises' argument is based on territoriality, his objection seems to lie in the fact that individuals cannot in themselves be administrative territorial units. Just imagine if the territorial principle is taken down to an individual level. It would mean that all individuals would have to be administrative (governmental and territorial) units in themselves and in regards to all of their private land property. They would have to be responsible for their own laws, law enforcement, court system, and so on, on all issues regarding their private land property..$^{21}$ While this certainly is possible, it does not seem to be very feasible and appears to be very far from an optimal solution, since it would require an undue amount of time and resources and it might possibly lead to a sort of tragedy of the anti-commons. ${ }^{22}$

21 To some extent I owe this interpretation to the renowned Swedish Objectivist Per-Olof Samuelsson, writing for his online magazine «Nattväktaren». Per-Olof Samuelsson writes, in Swedish: »Hur skulle en enskild individ kunna utgöra ett statligt förvaltningsområde? Som jag skrev i Vägen till laglöshet skulle detta innebära att varje enskild individ stiftar sina egna lagar och tar hand om sitt eget domstols- och polisväsende och beväpnar sig mot eventuella intrång från andra stater; och då skulle det inte bli minsta tid över för produktiv verksamhet.»

Further, and as an aside, Samuelsson points out that Mises also talks about secession of a village or a province, and he admits to being able to «imagine such a secession», even down to the level of a city block seceding. Yet, he nonetheless maintains that any secessionary unit would run into the same problem that the individual has, that is, the problem of having to make your own laws, take care of your own justice and police system as well as arm the village or the city against intrusions, and that the larger the administrative unit the less the problem would be.

First of all, Per-Olof Samuelsson, and indeed Mises himself, is taking the concept of territoriality for granted, without really explaining why. Second, it is also hard to get away from the fact that Per-Olof Samuelsson's suggestion could easily be used as an argument in favor of a world state as a solution to the problem presented above. And indeed, wouldn't the concept if taken to its logical end imply that only a centralized world state would have the best capacity to centrally plan law, justice and police? As Mises himself, as well as Jesús Huerta de Soto, has shown, there are compelling economic arguments why this is not the case but rather the opposite. See on this Mises (1922), Mises (1921), as well as Huerta de Soto (2010).

22 This concept was proposed by Michael Heller in his article «The Ttragedy of the Anti-Commons», Heller (1998), and essentially means a coordination breakdown 
Thus we conclude by noting that Mises' objections to individual secession are based on his conception that governance has to be territorial, and if this assumption is correct, we agree with Mises that there might indeed be compelling technical considerations why this, economically, might not be feasible. However Mises' assumption that all governance has to be territorial is unfounded. Once this assumption is removed and replaced with the concept of non-territorial or extraterritorial governance we can see that Mises' argument in favor of individual secession is sound and the compelling technical considerations he mentions disappear completely.

IV

\section{THE CONCEPT OF EXTRATERRITORIALITY}

As has been pointed out previously, the governance system that we have today can best be described as territoriality or territorial governance. The guiding principle of this form of governance is that every state possess absolute and exclusive jurisdiction over all persons and things within its territorial borders, and that wherever you are in the world today you more or less have to submit to the «laws of the land» whether you approve of them or not. ${ }^{23}$

The system of extraterritoriality, however, offers a distinctly different solution and in reality the two systems cannot be considered as being anything less than opposites.

\footnotetext{
due to there being too many competing interests. Of course, the free market has a way of dealing with coordination issues and solving them quickly and painfully. However, as can be expected with any intervention (such as the maintenance of an arbitrary and erroneous concept of territoriality) problems are bound to arise. Thus, just as its sister concept, the tragedy of the commons, the tragedy of the anti-commons is an effect of intervention into the free play of the market.

23 Johnson (n.d.).
} 


\section{Theoretical overview}

Extraterritoriality differs from territorial governance in at least two very important aspects.

First of all, it is in essence a non-territorial form of governance. Under extraterritoriality, the laws, instead of following the land as they do under territorial governance, follow the person. Thus, if we under extraterritoriality were to talk about Spanish or Swedish law then we would not be talking about the law as it applies on a specific territory but rather the law as it applies to a Spanish or a Swedish citizen. ${ }^{24}$ From this naturally follows that offenses are considered as being invasions of individual rights and not crimes against the state. ${ }^{25}$

The second way in which extraterritoriality differs from territorial governance is in regards to conflict resolution. How are cases that deal with two people of differing laws to be treated and solved? Generally and historically conflicts under extraterritoriality have been solved by the principle of actor sequitur forum rei, which means that the plaintiff would follow the defendant into his court. ${ }^{26}$ Today, in our age of territorial governance, this principle has come to mean that it is the territory where the crime is committed that determines the competent court for handling the case. ${ }^{27}$ Under non-territorial governance however it is the law of the accused, of the defendant, that is to be used and not that of the accuser, the plaintiff. In order to explain this more graphically, this table might be of some help:

24 It is true that extraterritoriality in one sense still «refers back» to a territory, since the laws that apply to the person are derived from a specific territory. Yet the essence of the concept of extraterritoriality is that the law applies to the individual regardless of what territory he happens to be on. Thus we can say that what we are really arguing for in this paper might be called, by a better name, non-territoriality.

25 Casey (2010).

26 However, as will be seen later, occasionally regarding more serious offenses, such as murder, the law of the slain and not the law of the slayer have historically been applied. See chapter Chapter IV, Europe. Other examples are where the defendant and the plaintiff each choose half the arbitrators. See Chapter IV, Iceland $\left(10^{\text {th }}-13^{\text {th }}\right.$ century).

27 Johnson (n.d.). 
TABLE 1

CONFLICT RESOLUTION UNDER EXTRATERRITORIALITY (PRINCIPLE)

\begin{tabular}{|c|c|c|}
\hline \multicolumn{3}{|c|}{ Defendant } \\
\hline Plaintiff & Citizen of A & Citizen of B \\
\hline Citizen of A & A settle dispute. & B settle dispute. \\
\hline Citizen of B & A settle dispute. & B settle dispute. \\
\hline
\end{tabular}

While it might at first strike the reader as odd that the accused is to be judged by his own laws, we need only imagine the opposite in order to understand why it is not so strange after all. The opposite would imply that people would be required to follow the way of living that other people preferred, which certainly is not very peaceful or conflict reducing. Instead, the peaceful and conflict reducing way of dealing with offenses is if the defendant is judged by his own court, according to the laws and customs that he follows. Thus, if we are to reuse our previous example, if a Spanish citizen commits a crime against a Swedish citizen, then the forum of the case would be Spanish, and a Spanish judge would judge according to Spanish law and custom, as is demonstrated in the table below:

TABLE 2

CONFLICT RESOLUTION UNDER EXTRATERRITORIALITY (COUNTRIES)

\begin{tabular}{|c|c|c|}
\hline \multicolumn{3}{|c|}{ Defendant } \\
\hline Plaintiff & Citizen of Sweden & Citizen of Spain \\
\hline Citizen of Sweden & Sweden settle dispute. & Spain settle dispute. \\
\hline Citizen of Spain & Sweden settle dispute. & Spain settle dispute. \\
\hline
\end{tabular}

We can also add a third condition, which can generally be said to be common, although not necessarily so. Since offenses are considered as being invasions of individual rights, i.e. torts or 
civil offenses, they are punished by a monetary restitution being owed to the victim and not the territorial monopolist (state). ${ }^{28}$

\section{Historical Examples}

Having briefly looked at the theory of extraterritoriality we turn to some historical examples. The truth is that there exist a multitude of examples of systems of non-territorial governance, but before we take a closer look at some of them we need to keep in mind that we only know what has been written down and preserved for later generations. ${ }^{29}$ Thus, the examples presented below are only the documented traces.

However, likely the system of non-territorial governance is as old as mankind itself. Indeed, for much of mankind's existence the concept of territoriality either did not exist or had a vastly different meaning than it has today, since the older generations of humans lived as nomads or as bands, or in territorially dispersed communities without strict borders. In such communities concepts of law, morals and conduct appeared, likely in a memorized form passed down to younger generations orally. Under these conditions it seems only natural that the law would follow the person and not the territory and as a rule, when meeting a stranger, it would have been natural to assume that they lived according to different laws and morals. Thus, as Richard C.B. Johnson points out, the common question regarding a stranger's origins, Sub qua lege vivis?, ${ }^{30}$ referred not just to place of birth or ethnicity but to his laws and customs as well.

Further, in order not to be imposed laws and morals that one did not approve of it appears as only natural to show restraint and try not to impose one's own laws and one's own morals on

28 Casey (2010)

29 It need also be pointed out that the examples we list here in no way is meant to be exhaustive. Other examples include in the Levant and Africa. For the interested reader that would like to have more historical examples explained in more detail, see Shih Shun Liu, «The Rise and Decline of Extraterritoriality» (Liu 1925).

30 Under/according to what law are you living? 
strangers. And in order to resolve a conflict and avoid further conflicts, it seems further only natural to let the defendant be judged by his own kind and according to his own laws. ${ }^{31}$

\section{Egypt, Greece, Rome and Mediaeval Europe}

Some of the earliest documented traces of extraterritoriality are to be found in ancient Egypt. As was pointed out earlier, the sort of territorial governance and sovereignty that we today take for granted was unheard of in the ancient world, and rather than territory it was race, nationality or religion that formed the basis of what law one belonged to. Thus, as Liu points out,

an identity of religious worship seems to have been during this period a necessary condition of a common system of legal rights and obligations. The barbarian was outside the pale of religion, and therefore incapable of amenability to the same jurisdiction to which the natives were subjected [footnote omitted]. For this reason, we find that in the ancient world foreigners were either placed under a special jurisdiction or completely exempted from the local jurisdiction. In these arrangements for the safeguarding of foreign interests we find the earliest traces of extraterritoriality. ${ }^{32}$

In ancient Egypt this was generally true for foreign merchants and especially true for Greek merchants, who were allowed to be judged according to their own laws and customs by their own judges in disputes regarding mercantile transactions. ${ }^{33}$

In ancient Greece, special magistrates called Xenodikai were instituted in order to be involved in questions relating to foreigners. Their involvement ranged from having full judicial power in making decisions regarding the dispute in question, to merely investigating the case and delivering the results to the ordinary magistrate, who was responsible in the making of the final verdict. ${ }^{34}$

\footnotetext{
31 Johnson (n.d.).

32 Liu (1925), p. 23.

33 Liu (1925), p. 24

${ }^{34}$ Liu (1925), p. 24.
} 
Similarly, in Rome there existed a magistrate, praetor peregrinus, which was given authority to deal with disputes between peregrines, and between peregrines and Roman citizens. In Roman law, peregrines were not considered to be true foreigners or strangers. Rather, they were subjects of Rome even if they were neither citizens nor Latins. ${ }^{35}$ While this system might not necessarily represent a perfect example of the later system of extraterritoriality it nonetheless gives us an early example that bears a resemblance to it. What's more, it also shows the kind of extralegal status that was given to foreigners in the ancient world. It is also in Rome that we find an early development and seed for later the developments of International Private Law.

Other examples in the Roman Empire can be found in Cadiz where Emperor Claudius (41-54 A.D) gave the merchants the privilege of choosing their own magistrates. Under Justinian (483565 A.D) the Armenians were judged by the same laws as the Romans, except in certain matters regarding for example marriage and succession to property. These cases were left to be either settled by the Armenians themselves or by a magistrate that was appointed by the Emperor and charged with the duty of administering Armenian law. ${ }^{36}$

With the downfall of the Roman Empire there developed, in Mediaeval Europe, a system of personal jurisdiction, which seems to have been based mostly on racial consanguinity. This meant that in the same country, or even city, people of different laws were living together. The Spanish born priest and archbishop of Lyon, Bishop Agobard, tells us that in these times,

it often happens that five men, each under a different law, would be found walking or sitting together. ${ }^{37}$

As further examples of this, the Goths, the Franks and the Burgundians each lived under their own laws when they were

35 However, the office of praetor peregrinus disappeared after 212 A. D. when Roman citizenship was extended to all provincials in the Empire. Liu (1925), p. 26.

36 Liu (1925), p. 27.

37 Liu (1925), p. 28. 
living in the same country. In the laws of the Visigoths we also find the provision that disputes between foreign merchants are to be settled by officers of their own nations, according to their own laws, without Visigoth involvement. ${ }^{38}$

In conclusion, while all the cases presented above, especially the earlier ones, are not necessarily perfect examples of extraterritoriality, they nonetheless at least show the sort of special, extra-legal, status that was awarded to foreigners in the ancient world, ${ }^{39}$ and they also hold the seeds to the later development of extraterritoriality and the current international private law.

\section{The Hanseatic League $\left(13^{\text {th }}-17^{\text {th }}\right.$ Century)}

The Hanseatic League was a trade federation consisting of German merchants and their corresponding market towns which dominated Northern European trade between the $13^{\text {th }}$ and $17^{\text {th }}$ centuries. The origin of the Hanseatic League is to be found in the city of Lübeck, which could also be considered as its center. One of the cardinal principles of the Hanseatic League was the absolute independence of its members of all foreign jurisdictions wherever they resided or traded, and they were instead to be

38 The Visigothic Code expressly states: «When any legal cause of action arises between foreign merchants, it shall not be heard by any of our judges, but by their own, and it shall be decided according to their own laws.» Scott (1910), p. 358. S.P. Scott, the editor and translator into English 1910 version of The Visigothic Code, comments on this by saying that «this law, which grants to every foreign trader the privilege of being judged by his own magistrates, is the precursor to modern legislation establishing consular and other tribunals instituted to protect the commercial interests, and define the judicial rights, of persons transacting business in another country, and is of unknown antiquity. It is, however, at least thirteen hundred years old. A people capable of appreciating and adopting such a measure, must have had intelligent conceptions of the maxims and requirements of international law and have made no inconsiderable progress in the arts of civilization", Scott (1910), p. $358 \mathrm{fn}$. Worth noting here is also that S. P. Scott makes the same point that we will make later, that this system is a precursor to International Private Law.

39 As Bruce L. Benson writes, regarding the Law Merchant, «by the twelfth century, mercantile law had developed to a level where alien merchants had substantial protection in disputes with local merchants and "against the vagaries of local laws and customs"». Benson (1990), p. 32. 
judged according to Hanseatic, or Lübeck, law. In other words they demanded extraterritorial rights wherever their merchants happened to be. Liu points out that,

in the twelfth century, Lübeck enjoyed such exemption in Wisby, and acquired the right to transfer the privilege to other cities [footnote omitted]. From about the same time, the German merchants and other inhabitants of Wisby on the island of Gothland in the Baltic enjoyed similar privileges in the Republic of Novgorod in Russia [footnote omitted]. ${ }^{40}$

For instance, the privileges given to the German merchants and inhabitants of Wisby in the Republic of Novgorod ${ }^{41}$ in 1229 had the following provisions. If a Ruthenian ${ }^{42}$ committed an offense against a guest ${ }^{43}$ the duke and alderman of Novgorod would be informed and they would settle the case. If, however, an offense was committed by a guest against a Ruthenian it was the alderman of the guests that was to be informed. ${ }^{44}$ This is fully in accordance to the principle of actor sequitur forum rei.

Furthermore, no one had any right to take the offender by force. Instead it was up to the alderman of the guests to bring the offender to reason. The court of the guests was also off-limits for the locals. Only a messenger sent by the duke of Novgorod was allowed entrance. The local guards, the so called biriz, were not even allowed to go up to the entrance of the court. ${ }^{45}$

As for the actual offenses, regardless of the severity they seem to have been viewed as civil offenses, torts, with a monetary restitution being owed to the victim. The amount of monetary restitution needed to be paid varied in relation to the victim's social status. For instance, the restitution that was owed in the killing of any person was set at ten marks of silver, but in the case of the killing of a priest, an alderman or a messenger this

\footnotetext{
40 Liu (1925), p. 30.

41 The Republic of Novgorod was the eastern most port of the Hanseatic League.

42 Present-day Ukraine, Belarus, Poland, and Slovakia.

${ }^{43}$ Guest here refers to German merchants or an inhabitant of Wisby in Novgorod.

${ }^{44}$ Cave and Coulson (1936), p. 228.

45 Cave and Coulson (1936), p. 228.
} 
amount was doubled to twenty marks. A man's servant was atoned for by three marks of silver, the wounding of a freeman two marks of silver and the wounding of a serf half a mark of silver. The slapping of another person was to be amended for by paying half a mark of silver as well. ${ }^{46}$

Further, a clear example to the special status that was granted guests, if a Ruthenian owed a debt to both a guest and a Ruthenian, he had to pay the debt to the guest first, and only later to the Ruthenian, and if he did not have enough money to pay the guest he would be forced into the servitude of the guest. However, before this happened, the guest first had to publicly offer the offender up for redemption, through which other people could pay off the debt to the guest, and, so to speak, redeem the offender. ${ }^{47}$

A concluding example can be found in Scania, ${ }^{48}$ where the Hanseatic settlements were mostly temporary, with merchants mainly staying over the summer, due to hostility ${ }^{49}$ toward Hanseatic merchants from the Danish crown. Regardless, the Hanseatic merchants were eventually granted the right to choose their own judges in order to be tried according to Lübeck law in 1361 and $1368 .{ }^{50}$

\section{Iceland $\left(10^{\text {th }}-13^{\text {th }}\right.$ century)}

The story of Iceland is a curious and highly interesting one. According to «The Book of Settlements» ${ }^{51}$ most of the settlers to Iceland escaped Norway and the power ambitious king Harald

46 Cave and Coulson (1936), p. 229

47 Cave and Coulson (1936), p. 229.

48 While Scaniais in present-day Sweden, in those days it belonged to the Danish crown.

49 This hostility eventually led to an armed conflict. Together with Sweden, whose city Stockholm was one of Scandinavia's largest Hanseatic colonies, Mecklenburg and Holstein, as well as the Danish nobility, the Hanseatic League eventually raised an army and defeated the Danish crown, taking control of the Scania market for 15 years, from 1370. Dollinger (1999), p. 70.

50 Liu (1925), p. 34.

51 In Icelandic: Landnámabók. 
the Fair-haired, the king who is often given credit for the unification of some parts of Norway. The fact that most settlers in Iceland escaped a power ambitious king accounts for the fact that Iceland has never had a king. ${ }^{52}$ It also accounts for a period of almost 300 years that was characterized by highly decentralized and indeed non-territorial governance. There were no bureaucrats, no taxes, no police and no army, but rather what was needed was provided privately, such as fire-fighting, criminal prosecution, and care of the poor. ${ }^{53}$ Most of what we know of the Icelandic system comes from a highly developed collection of literary works that was produced during these years, the so called Sagas of Icelanders, which describe events that took place in Iceland between in the $10^{\text {th }}$ and $11^{\text {th }}$ centuries.

As stated previously, the Icelandic system was a non-territorial one and did not have any kings. Instead of kings there were local chieftains, goði, ${ }^{54}$ who were responsible for creating a (pagan) temple and serving as its priest. ${ }^{55}$ The congregation was called the goðorð. The relationship between the goði and his congregation, his thing men, was based on a voluntary contract and furthermore it was non-territorial since the thing man could change his allegiance to another goði without having to move to a new geographical location. ${ }^{56}$ Thus we see that the Icelandic system of governance was a non-territorial, or extraterritorial, system of governance, which effectively granted the right to secession down to an individual level.

In the case of a conflict resolution the members of the court system were chosen after the crime had happened, with the defender and plaintiff each choosing half the arbitrators. There was no public property, but all property was private, and there was no division between what we now consider to be crimes and civil offences. Rather, all crimes were considered offenses against

\footnotetext{
52 Roderick Long writes that "The $11^{\text {th }}$-century historian Adam von Bremen described Iceland as having «no king but the law.», Long (2002).

53 Long (2000).

54 The Icelandic letter «ठ» is roughly equivalent to the letter « $\mathrm{d} »$ only pronounced slightly differently.

55 Whiston (2002).

56 Friedman (1973).
} 
an individual and his property, and if a crime was found to have been committed, the offender was forced to pay a fine to the victim. If the offender was unable to pay the fine himself he would have to either find someone else to help him pay, or if this was not possible, he could also work off his fine in the form of slavery. However, if the offender did not pay his fine or submit to slavery he was simply outlawed and was forced to live outside of the law. ${ }^{57}$

The sentence of outlawry could be either of a lesser extent (Fjörbaugsgarður) or of a greater extent (Skóggangur). A lesser outlaw had to live outside of the protection of the law, i.e. leave the country, for three years. A greater outlaw had to leave the country permanently, and he could be rightfully killed after three months of outlawry. ${ }^{58}$

Enforcement of judgments, i.e. the collection of restitution, was left fully in the hands of the victim. In order to incentivize the payment of restitution, the law most often specified when the payment should be done and failure to do so on time was in itself considered to be a crime. ${ }^{59}$

One might immediately react to the fact that it was the victim himself who was responsible for collecting the restitution from the aggressor. What about the poor victims, those with very limited resources to enforce judgments in their favor? Weren't they simply left at the mercy of the rich and powerful? Not at all. This was solved by actually allowing the victim to sell his judgment to someone that was stronger than himself and more capable of enforcing it. ${ }^{60}$

As David Friedman points out,

The Icelandic system dealt with this problem by giving the victim a property right-the right to be reimbursed by the criminal-and making that right transferable. The victim could turn over his case to someone else, either gratis or in return for

\footnotetext{
57 Whiston (2002).

58 Runolfsson Solvasson (n.d.).

59 Runolfsson Solvasson (n.d.).

60 Runolfsson Solvasson (n.d.).
} 
a consideration. [Footnote omitted] A man who did not have sufficient resources to prosecute a case or enforce a verdict could sell it to another who did and who expected to make a profit in both money and reputation by winning the case and collecting the fine. This meant that an attack on even the poorest victim could lead to eventual punishment. ${ }^{61}$

Indeed, the willingness among Icelanders to pay up once found guilty was so remarkable that even in times of war it was still simply assumed that every man that was killed would have to be paid for at some point, which helped make any violent conflict very short lived. As Friedman recounts,

there is a scene in Njal's Saga that provides striking evidence of the stability of this system. Conflict between two groups has become so intense that open fighting threatens to break out in the middle of the court. A leader of one faction asks a benevolent neutral what he will do for them in case of a fight. He replies that if they are losing he will help them, and if they are winning he will break up the fight before they kill more men than they can afford![footnote omitted] Even when the system seems so near to breaking down, it is still assumed that every enemy killed must eventually be paid for. ${ }^{62}$

As is clear, both fighting parties had very strong incentives to stop the fighting and settle as fast as possible because any type of long lived and ongoing violence would end up being very costly, and was thus effectively discouraged. The Icelandic system seems to have had strong incentives, mostly monetary, that made sure that the enforcement of a judgment was carried out and Icelanders also seem to have been very keen on compromising in both major and individual disputes. ${ }^{63} \mathrm{In}$ fact, contrary to popular opinion, such as for instance regarding the Wild West, ${ }^{64}$

\footnotetext{
61 Friedman (1973)

62 Friedman (1973).

63 Runolfsson Solvasson (n.d.).

64 See for instance the article, «An American Experiment in Anarcho-Capitalism: The -Not So Wild, Wild West», Anderson and Hill (1977).
} 
the Icelandic system does not seem have been particularly violent. Friedman concludes his explanation of the Icelandic system by stating that,

the quality of violence, in contrast to other medieval literature, is small in scale, intensely personal (every casualty is named), and relatively straightforward. Rape and torture are uncommon, the killing of women almost unheard of; in the very rare cases when an attacker burns the defender's home, women, children, and servants are first offered an opportunity to leave. [footnote omitted] One indication that the total amount of violence may have been relatively small is a calculation based on the Sturlung sagas. During more than fifty years of what the Icelanders themselves perceived as intolerably violent civil war, leading to the collapse of the traditional system, the average number of people killed or executed each year appears, on a per capita basis, to be roughly equal to the current rate of murder and non-negligent manslaughter in the United States. ${ }^{65}$

In conclusion, the Icelandic case was a non-territorial governance system, where the laws followed the person, the thing man, and not the land. Individual secession was granted to the thing man as he could change allegiance without having to move to another geographical location. Law, courts, enforcement and police were provided on a private and contractual basis, and yet despite this chaos did not break out. Even when the system eventually broke down in what was considered an intolerably violent civil war the violence was on par with present day USA. The Icelandic system lasted for roughly 300 years until it eventually broke down in 1262 after a civil war led to a centralization of power. ${ }^{66}$

65 Friedman (1973).

66 As a comparison, it took only 85 years for a civil war to break out in the United States of America. While this is not the place to speculate as to why the Icelandic system eventually broke down, as Long points out, "We should be cautious in labeling as a failure a political experiment that flourished longer than the United States has even existed.» For Long's explanation of why the Icelandic Commonwealth broke down, see Long (2002). 


\section{China and The Far East}

The case of China and the Far East is a more recent example of extraterritoriality, from the $17^{\text {th }}$ century and lasting up until the beginning of the $20^{\text {th }}$ century. Contrary to the previously stated examples, extraterritorial rights in China were never conceded voluntarily but rather it had to be forced upon the Chinese by treaty. ${ }^{67}$ The reasons as to why foreign nations demanded to be granted extraterritorial rights in China are to be found in the feeling among westerners that the Chinese legal system was deficient. However, while most westerners might have viewed the Chinese system with suspicion, it cannot be considered to have been barbaric and uncivilized. As Liu writes,

Even Caleb Cushing, who regarded the extension of extraterritoriality to non-Christian peoples as a rule of international law, refuted the argument of civilization. «Europeans and Americans,» he said, « had a vague idea that they ought not to be subject to the local jurisdiction of barbarian Governments, and that the question of jurisdiction depended on the question, whether the country was a civilized one or not; and this erroneous idea confused all their reasonings in opposition to the claims of the Chinese [footnote omitted]; for it is impossible to deny to China a high degree of civilization, though the civilization is, in many respects, different from ours» 68

The first people to be granted exemption from local Chinese law in China were Arabians in the $9^{\text {th }}$ century, and the first western foreigners that were allowed to live under their own law in China were Russians. This was the result of an agreement that was reached between Russia and China in 1689 that stated that,

If hereafter any of the subjects of either nation pass the frontier and commit crimes of violence against property or life, they are at once to be arrested and sent to the frontier of their country and handed over to the chief local authority for punishment. ${ }^{69}$

67 Liu (1925), p. 79.

68 Liu (1925), p. 84.

69 The Maritime Customs. Treaties, Conventions, etc. between China and Foreign States (1917), p. 6. 
This right was however only granted to Russians in China (and to Chinese in Russia). Other westerners were forced, as before, to submit to local Chinese law. Before the Opium War, the British had tried, through legislation, on many occasions to introduce extra-territorial jurisdiction into China, but all their attempts had failed. It was only after the first Opium War had finished in 1842 that extraterritoriality was introduced in China for British citizens. ${ }^{70}$

The Americans started arguing for an extraterritorial treaty, after an incident that involved an American sailor who was charged with the killing of a Chinese citizen, which left the American authorities displeased with the Chinese legal system and less eager to hand over their people to the Chinese justice system. ${ }^{71} \mathrm{~A}$ deal was eventually reached in 1844, and it became the main agreement that all other subsequent agreements were based on. ${ }^{72}$ A common feature of all these agreements was that they were non-mutual, that is to say, they applied only to foreigners in China but not to Chinese people in foreign countries. When it came to cases of dispute resolution, the following four categories of disputes were stipulated. They are jurisdiction in cases between

1) Natives: In these cases it was generally implied that the native authorities administered the law without interference.

2) Foreigners of the same nationality: These cases were decided by their own officials according to their own laws and usages, without native interference.

70 The actual grant of extra-territorial right was given by China to Great Britain in July of 1843. Liu (1925), p. 97.

${ }^{71}$ See the special edition of China Weekly Review dealing with a debate against and in favor of extraterritorial rights. The article states: «From the standpoint of the Americans there had been a cases where a sailor on an American ship had accidentally killed a Chinese. The Chinese demanded that the sailor be handed over to the Chinese authorities, which was done. No Americans were permitted to appear at the trial and give testimony and the sailor was adjudged guilty and executed by strangulation. Following that incident the Americans naturally refused to hand over any more of their nationals accused of crimes by the Chinese.» Powell (1925), p. 9.

72 Including countries such as Belgium, Denmark, Holland, France, Italy, Japan, Norway, Portugal, Spain, Sweden, Brazil, Mexico, Peru, and Switzerland. 
3) Natives and foreigners: In these mixed cases the principle of actor sequitur forum rei was generally adopted..$^{73}$ That is, if a native committed a crime against a foreigner he was to be judged according to native law, and if a foreigner committed a crime against a native he were to be judged by foreign law. In civil cases between a native and a foreigner, it was the consul of the foreign power that was given the right to settle the case and see to it that both parties were pleased. If he failed to do so the consul had the assistance of local authorities. Together with local authorities the merits of the case were examined and decided. However, the final decision was according to the principle of actor sequitur forum rei, that is, it was in the hands of the official of the defendant's nationality. The official of the plaintiff's nationality was merely assigned the role of an assessor. ${ }^{74}$

4) Foreigners of different nationalities: Disputes between foreigners of different nationalities were settled according to whatever treaties existed between the two nations without native interference. The settled rule in these cases, according to Liu, was again the principle of actor sequitur forum rei.

Other countries in the Far East where westerners enjoyed extra-territorial rights were Japan, Korea, Siam, ${ }^{75}$ Borneo, Tonga and Samoa.

\section{The Decline of Extraterritoriality and Present Day Examples}

While the case of China shows a rather recent case, the truth is that the importance of extraterritoriality declined sharply after the Peace of Westphalia, in 1648, a treaty which accepted territorial sovereignty as a fundamental principle of international intercourse. $^{76}$ This decline likely had to do with the dynastic and colonial power struggles that that marked the $16^{\text {th }}$ and $17^{\text {th }}$ centuries,

\footnotetext{
73 Liu (1925), p. 59.

74 Liu (1925), p. 59.

75 Present day Thailand.

76 Liu (1925), p. 37.
} 
initiated by the discovery of the Americas. ${ }^{77}$ Despite this there still exist some traces of extraterritoriality today.

\section{International Private Law}

International Private Law (also known as Private International Law or Conflict of Laws) is a set of procedural rules meant to determine which legal system and which jurisdiction applies in a dispute between two or more conflicting legal systems. It is distinct from Public International Law in that it deals with private entities (individuals, companies, etc.) whereas Public International Law deals with treaties between governments. It can be either international (between different nation-states) or intra-national, as is the case between different states in a federal system.

As was mentioned earlier, a significant development of International Private Law can be found in the aforementioned case of Rome and the magistrate praetor peregrinus. The modern theory of International Private Law is however considered to have originated in Italy and especially through the works of Bartolus of Sassoferrato. ${ }^{78}$

As Joseph Henry Beale notes,

[Bartolus'] text is the starting point and the cited authority for all subsequent work on the subject for five hundred years. ${ }^{79}$

Likely the origin of the conflict of laws sprang out of the need to adjudicate disputes between traders belonging to different city states in Italy. In order to do so, certain laws were found to be personal and follow the person (statuta personalia), whereas other laws were found to follow the land (statuta realia). The similarities to the concept of extraterritoriality should be obvious.

An example of Private International Law is the Admiralty Law, or the Maritime Law, which deals with relationships between

\footnotetext{
77 Liu (1925), p. 37.

78 Bartolus (1914).

79 Bartolus (1914), p. 9.
} 
private entities and their ocean going vessels. Among the earliest historical records of maritime law we find the customs of the Hanseatic League which we previously mentioned, and traces can also be found in the way ships entering foreign harbors even today still carry and submit to the chosen flag. ${ }^{80}$

\section{Functionally Overlapping Competing Jurisdictions (FOCJ)}

The concept of Functionally Overlapping Competing Jurisdictions (FOCJ) is a recent concept brought forth by Bruno Frey. ${ }^{81}$ The idea of FOCJ has many similarities with the ideas regarding nonterritorial governance presented above and therefore it deserves some closer attention, since FOCJ allows for multiple governments to reside in the same territory. It also allows for governments to exist without any corresponding territory at all.

The FOCJ would be defined by the functions (i.e. "public services») they perform. Since these services are not necessarily related to any specific territory they would naturally overlap with other competing governments. This competition, and non-territoriality, means, as Professor Frey puts it, that

membership in a particular FOCUS (the singular of FOCJ) can be discontinued without changing one's location. Exit is not restricted to individuals or firms; political communities as a whole or parts of them may also exercise this option. Moreover, exit may be total or only partial. In the latter case, an individual or community participates in only a restricted set of FOCUS activities. ${ }^{82}$

As can be seen, this is to a large extent similar to what have been presented previously in the text, historically (as in the case

80 As an aside, the pirate tradition of hoisting a black flag was a ploy used to scare the soon-to-be-attacked victims of pirates into surrendering without a fight, since the black flag signaled that the attackers were outlaws, living outside of the law, and for this reason might not hesitate to kill everyone onboard the attacked vessel. Johnson (n.d.).

81 Frey (2001).

82 Frey (2001), p. 105. 
of Iceland) and theoretically. Nonetheless, some deviations exist, and they need to be briefly dealt with.

Professor Frey's idea of FOCJ is to create a new federalism that, among other things, «is based on well-defined members and boundaries according to the public functions to be performed, and thus is comparable to a club» (my italics). Yet, at the same time he points out that «A FOCUS is a democratic governmental unit with authority over its citizens, including the power to tax.» (my italics) ${ }^{83}$ To this we need only turn to what Joseph Schumpeter had to say in the matter,

The theory which construes taxes on the analogy of club dues or of the purchase of the services of, say, a doctor only proves how far removed this part of the social sciences is from scientific habits of mind. ${ }^{84}$

Indeed.

Voluntarily paying a fee in order to be part of a club is of course not the same as being forced to pay taxes. Taxation and voluntary payments are two qualitatively distinct concepts.

Moreover, if we are to take Bertrand de Jouvenel's distinction between power and authority, taxation is found to be completely incompatible with authority (but of course still perfectly compatible with power). As de Jouvenel writes,

Power, however, is something very different from authority. The distinguishing mark of the latter is that it is exercised only over those who voluntarily accept it: if the rulers have authority over only a part of their subjects, they may receive from that part a strength sufficient to subject the others to their power [...] Authority ends where voluntary assent ends. ${ }^{85}$

If we are to accept this definition then taxation is completely incompatible with authority, for if the payment for services rendered is made voluntarily and thus compatible with authority,

\footnotetext{
83 Frey (2001), p. 106.

84 Schumpeter (1942), p. 198.

85 Hoppe (2000), p. 17.
} 
then the payment does not constitute taxation at all but merely a normal fee. On the other hand, if the payment is not made voluntarily, which taxes are not since they are extracted at the point of a gun, then it is incompatible with authority. ${ }^{86}$

Nonetheless, Frey's development of the idea of Functionally Overlapping Competing Jurisdictions is worth exploring in more detail. Once we remove taxation and replace it with voluntarily paying customers, the concept looks much like what is being proposed in this paper.

\section{$\mathrm{V}$ \\ PROPERTY, EXTRATERRITORIALITY AND INDIVIDUAL SECESSION}

Before we dive into the solution to Mises' problem, which might already be obvious to some, we need to discuss some concepts as they relate to territory and territoriality, especially the distinction between land property and territory.

\section{Land property vs. Territory}

Property in land is a fairly straightforward concept. Property starts from the concept of self-ownership, that is, that every man has a right over his own body. ${ }^{87}$ Further, in the world there are only things. Man turns things into goods when he recognizes that the thing has a value to him and appropriates it and makes it part of his own property. This is the concept of original appropriation.

From this we can deduce that property is something that is owned by some person (private property), a group of people (common property) or an entity (such as a corporation). Properties

${ }^{86}$ Furthermore one might ask if Frey's conception of the FOCUS is one that can unilaterally increase the price of its services. If so, then who in their right mind would ever patron that particular FOCUS?

87 As Rothbard has shown, the alternatives to full self-ownership are bizarre. See Rothbard (1982), pp. 44-46. 
can exist in a movable (such as a book) or non-movable form (with the prime example being land). ${ }^{88}$

Being his property, the owner has the full right to do as he pleases with his property to the extent that it does not interfere with other people's right to do the same. This includes, but is not necessarily limited to, the right to use, add to, abandon, destroy, consume, sell, exchange, and transfer it as well as exclude others from doing these things. However, it must again be pointed out that the property owner can only do these things to the extent that he does not violate other property owners' property.

In relation to land property this means that I have the full right to exclude anyone I seem fit, on whatever grounds, from my land ${ }^{89}$ and if an unwanted person nonetheless enters my property I have the right to forcefully evict him. However, in doing so I need to be careful that I do not violate his property and escalate the use of force too much. ${ }^{90}$ The same is true when it comes to movable property. While I do have the right to claim a stolen item, such as a book, back from the thief I do not have a right to kill the thief on the spot. Rather the use of force can only be escalated in very much the same manner as in the case of land trespass.

88 Some theorists also argue for another distinction, and that properties can be either material (a table) or immaterial (patents, copyright). Since this is not a paper on intellectual property, or even property, I will not dive into this discussion but rather refer the reader to some further reading on the subject which I tend to agree with. See Kinsella (2008) and Boldrin and Levine (2008). On the general subject of property see also Schaffer (2009) LeFevre (1966).

89 Hoppe (2000), pp. 137-149.

90 As Walter Block argues this eviction principle «stems from the non-aggression principle (NAP): in countering a rights violation, we want to ensure that we stop just on this side of violating the rights of the rights violator. So, if A sees B stepping on his lawn, as a first step A may not blow B away with a bazooka. Rather, A must notify B of his trespass, and if B immediately ceases and desists, perhaps even with an apology thrown in, that is the end of the matter. It is only if B turns surly, hostile and aggressive, and refuses to budge, that A may properly escalate. Not, immediately, to the bazooka stage, but a threat to call the police would not be considered at all inappropriate; even a physical push would not be untoward. If $\mathrm{B}$ at this point initiates physical aggression against A, say by pushing him back, throwing a punch at him, or pulling a gun or knife on him, then all bets are off, and A may appropriately escalate the violence sufficiently to protect himself and his property from invasion.» Block (2011), p. 5. 
In other words I do not have an absolute jurisdiction over the person that either holds my book or stands on my land.

Now, the concept of territory assumes that there is an essential difference between movable property and immovable property (land) such that an absolute jurisdiction does in fact exist in relation to immovable property (land).$^{91}$ Indeed one could say that the whole theory of the state rests on this rather dubious assumption. To repeat Max Weber's definition once again,

... a state $[\ldots]$ claims the monopoly of the legitimate use of physical force within a given territory. Note that «territory» is one of the characteristics of the state. ${ }^{92}$

A territory is a geographical area, a piece of land, over which an entity, i.e. a state, claims exclusive and absolute jurisdiction (monopoly of the legitimate use of physical force). That is to say, if you were to set your foot on this or that geographical piece of land you would become the subject of said entity (state) and have to submit to its absolute jurisdiction.

This means that the concept of territory is completely incompatible with self-ownership and private property. Once I step on a territory this absolute jurisdiction means that I am at the mercy of the controlling entity; I am no longer in full possession of myself or my property; I am subject to the absolute jurisdiction of the controlling entity to do as it sees fit with my body and property. Under territoriality then, all talk of property is empty. "Property», as well as rights and freedoms, only exists to the extent that the controlling entity allows them to exist. ${ }^{93}$

91 It is unclear why this right would not exist for movable property as well. I contend that this distinction is completely baseless. There is no essential difference between property in movable things and property in immovable things. Now, if absolute jurisdiction is given to things that one can step and stand on, what then if someone were to step or stand on my book? Do I then get absolute jurisdiction over that person's body and property?

92 Weber (1919), p. 1.

93 This is of course the intellectual foundation of Statism spelled out in full force. I can do no better than quote Albert Jay Nock in this regard: «In brief, what it [Statism] came to was that the State is everything; the individual, nothing. The 
a) Individual Rights vs. Territorial Rights

The distinction between land property and territory that we just made has further implications when it comes to the concept of rights.

As was stated, under territoriality all talk of property, rights, and freedom is idle. These things only exist to the extent that the territorial monopolist is willing to grant them, and they can just as quickly be revoked. It is assumed that rights are not inherent in anyone, nor based on his faculty, or condition, as a human being, but rather, «rights» are merely bestowed upon men by the grace of the territorial monopolist, and depends on what territory the person happens to be on at any given moment. This territorial and collectivist view of rights is of course completely incompatible with the concept of individual rights, which states that rights belong to human beings, individuals, alike.

For this reason we need to make one thing clear before we continue. A man's rights does not stem from him belonging to any particular territory (territorial rights). Rather they stem from the inescapable fact that we are acting human beings, individuals (individual rights). Thus while much has been written previously about extraterritoriality, what we are in reality talking about might have been better named if it had been called non-territoriality instead. After all, the rights of man does not stem from any particular territory but from his existence as a human being. Indeed the only governance theory compatible with individual rights is the concept of non-territorial governance, which of course is the same as a complete recognition of the principle of self-ownership and private property.

individual has no rights that the State is bound to respect; no rights at all, in fact, except those which the State may choose to give him, subject to revocation at its own pleasure, with or without notice [...] Moreover, since the State creates all rights, since the only valid and authoritative ethics are State ethics, then by obvious inference the State can do no wrong.» Nock (1943), pp. 114-115. 


\section{A non-territorial solution to the problem of individual secession}

We are now in a position to restate Mises' position in regards to individual secession and solve it with the concept of extraterritoriality. Mises maintains that,

if it were in any way possible to grant this right of self-determination to every individual person, it would have to be done. This is impracticable only because of compelling technical considerations, which make it necessary that a region be governed as a single administrative unit and that the right of self-determination be restricted to the will of the majority of the inhabitants of areas large enough to count as territorial units in the administration of the country. ${ }^{94}$

As we saw earlier, Mises' quarrel with individual secession was due to the fact that he considered it economically unreasonable for an individual to, in himself, be an administrative unit. This is so because every individual would then have to make his own law, and be responsible for his own law enforcement and court system, and make sure to arm himself in order to repel any and all invaders, and so on.

The main problem with Mises' reasoning is that he seems to take territorial governance for granted as being the only possible governance system, but we have seen that this is neither theoretically nor historically true. Extraterritoriality, or non-territoriality, solves, and has solved, this problem and makes it unnecessary for a seceding individual to be an administrative unit in himself, in much the same way that he, on a free market, does not have to be a self-sufficient producer of all the things that he wants. Rather, he would, just as before, use the services of a governing entity with the difference that this entity is not bound to any specific territory.

While it is by no means obvious a priori how this nonterritorial governing entity would resolve conflicts and function

94 Mises (1927), pp. 109-110. 
on the market, we have seen that this historically has been solved by giving foreign people on a particular territory extraterritorial rights. This allowed them to be judged by their own country's judges according to their own country's laws, according to the principle actor sequitur forum rei, which meant that the accuser followed the accused to his court.

We used a table to explain the workings of this principle, so let us return to it briefly:

TABLE 3

CONFLICT RESOLUTION

(UNDER TERRITORIAL GOVERNMENTS)

\begin{tabular}{|c|c|c|}
\hline \multicolumn{3}{|c|}{ Defendant } \\
\hline Plaintiff & Citizen of Sweden & Citizen of Spain \\
\hline Citizen of Sweden & Sweden settle dispute. & Spain settle dispute. \\
\hline Citizen of Spain & Sweden settle dispute. & Spain settle dispute. \\
\hline
\end{tabular}

It doesn't take a lot of imagination to convert the concept of citizen to the concept of customer, or to convert the (territorial) concept of country to the (non-territorial) concept of company. Awkward as this might seem at first, it is likely only because we have gotten used to thinking in a territorial way. But from an historical point of view, it is the system of territoriality, and not that of extraterritoriality, that is the anomaly. A way of imagining the functioning of an extraterritorial system in the world of today is to merely take the territorial governments, the Swedens, the Spains, the Germanys, etc., of today and strip them of their territorial connection, making them non-territorially bound companies instead. When we do so it becomes obvious that what we have said so far is very much compatible with the workings of conflict resolving insurance agencies (sometimes called PDAs [Private Defense Agencies]) as explained by Tannehill and Tannehill (1993), Rothbard (2006) and Hoppe (2003), among others.

Let us thus return to the explanatory table, but let us replace Citizen with Customer, and let us consider Sweden and Spain 
to be non-territorial private conflict resolving insurance agencies, PDAs A and B. ${ }^{95}$

TABLE 4

CONFLICT RESOLUTION

(UNDER NON-TERRITORIAL PDAS)

\begin{tabular}{|c|c|c|}
\hline \multicolumn{3}{|c|}{ Defendant } \\
\hline Plaintiff & Customer of A & Customer of B \\
\hline Customer of A & $\begin{array}{l}\text { PDA A will settle dispute } \\
\text { internally. }\end{array}$ & PDA B will settle dispute. \\
\hline Customer of B & PDA A will settle dispute. & $\begin{array}{l}\text { PDA B will settle dispute } \\
\text { internally. }\end{array}$ \\
\hline
\end{tabular}

Allowing for some conjecture, the PDAs that offer protection and judicial services on a completely free market would likely be linked to insurance agencies that offer insurance against damages incurred by other people. ${ }^{96}$ People would contract freely with these insurance agencies, and would be able to switch between insurance companies without having to move anywhere. I am struggling, and failing, to find a good metaphor here, but instead of having to "vote with their feet» they could just make the decision to change company by, for instance, making a simple phone call. ${ }^{97}$ There would likely be no public law, but rather all offenses would be treated as violations of individual rights, as civil offenses, with restitution being owed to the victim.

While the PDAs generally would insure the customer against damages, it is clear that this would not be true in all cases. Rather, as Hoppe points out,

95 This table should not be confused as something that is meant to represent the way conflicts should be resolved on a free market. Rather it is meant to show how conflicts might be, and historically has been, resolved according to the principle of actor sequitur forum rei. There is of course nothing that means that it will have to be this way.

96 Tannehill (1970).

97 The argument against the statement that it is easy to change your company by a phone call, is often that «it is not at all as easy as it sounds, because look at how difficult it is to switch mobile service or ISP provider!». To this one of course need only reply that at least one does not need to leave the country to change mobile service! 
... protection becomes an insurable good only if and insofar as an insurance agent contractually restricts the actions of the insured so as to exclude every possible «provocation» on their part. Various insurance companies may differ with respect to the specific definition of provocation, but there can be no difference between insurers with regard to the principle that everyone must systematically exclude (prohibit) all provocative and aggressive action among its own clients. ${ }^{98}$

The PDAs would not insure, or be responsible, if anyone of their clients violated these contractually stipulated prohibitions. As Hoppe again points out, insurers,

would offer their clients contracts with well specified property and product descriptions and clearly defined and delineated duties and obligations. ${ }^{99}$

Let us briefly consider what the prohibitions, duties and obligations would consist of.

The most obvious ones are clearly those aggressive behaviors that are in violation of the non-aggression principle, such as assault, theft, murder, rape, and threats thereof, but also, and just like any normal insurance policy, reckless behaviors such as, for instance, being drunk and swinging a baseball bat in front of the windshield of someone's car. In fact, to get a better idea of what these prohibitions, duties and obligations that PDAs would require of their customers in order to insure them in the first place we could consider them as being what we now consider as being «the law». This law would apply to the individual insurance taker, it would be highly individual and it would, so to speak, «follow him»

To conclude, we have seen that Mises was indeed correct in stating that if individual self-determination, or individual secession, were at all possible it would have to be given. By applying the concept of extraterritorial, or non-territorial, governance, we also see that he was incorrect in saying that there existed

\footnotetext{
98 Hoppe (2003), p. 348.

99 Hoppe (2003), p. 351.
} 
compelling technical considerations that made it impossible. Under non-territorial governance however, there is absolutely no need for the individual to be an administrative, territorial, governmental unit in himself, and this removes Mises' misgivings completely. Just as Mises points out, the right to self-determination stems from the rights of man, and indeed it is only by removing territoriality completely and allowing for individual secession that the rights of man can be fully maintained and the liberal program for peace and prosperity can be reached. Only in this way will no one be held against their will in an association that they do not want to belong to; and only in this way will conflicts between people and peoples be reduced to the largest extent possible.

\section{CONCLUSION}

The importance of the study of economics has never been put as forcefully as Mises so poignantly writes at the end of Human Action. Economics, he writes,

is the philosophy of human life and action and concerns everybody and everything. It is the pith of civilization and of man's human existence. ${ }^{100}$

While the preceding paper is not an economic paper in the strict catallactic sense, something which I readily admit, I would argue that it certainly is an economic paper in the broader and more generally praxeological sense. It is the aim of praxeology to study the logic of action. Through praxeology we can explain how institutions, such as language, money and law, voluntarily ${ }^{101}$

\footnotetext{
100 Mises (1949), p. 878.

101 The astute reader might notice that I do not use the commonly used word «spontaneous» to explain the process by which institutions appear. This is because I believe that the correct concept is one of a "voluntary order» rather than a «spontaneous order». Trying to describe human action and their results in terms of
} 
spring up on the market through human action. ${ }^{102}$ Law is not a creation of the centralized, top down, organization, but rather the result of a complex inter-tangled web of decentralized human actions and interactions. Bruce L. Benson has convincingly argued that before the coercive apparatus of the state appeared, law voluntarily emerged from custom in Anglo-Saxon England. He gives special attention to the Law Merchant which,

evolved into a universal legal system through a process of natural selection. As merchants began to transact business across political, cultural, and geographical boundaries, they transported trade practices to foreign markets. Those previously localized customs that were discovered to be common to many localities became part of the international Law Merchant. Where conflicts arose, practices that were the most efficient at facilitating commercial interaction supplanted those that were less efficient. ${ }^{103}$

Certainly an institution, such as the legal institution which was the subject of this paper, that has sprung up from, maintains, and creates the conditions for the best functioning of, the market itself deserves our attention. It is of great importance if we are to come closer to an understanding of the extremely complex web of human actions and interactions that gives rise to markets, and indeed society itself.

Our study is however far from being a complete one. I believe it is possible to extend our analysis by combining what we have

«spontaneity» is mildly misleading, since it brings in a concept that seems to be more fitting to the natural sciences and it is bound to lead to some confusion. Human actions do not just «happen» spontaneously but are rather signified by will, intention, reason, etc. Thus, what is generally referred to when one uses the term «spontaneous order» is merely an order that is «free of intervention», which of course in regards to human action simply refers to a voluntary order rather than a spontaneous one. This terminological confusion is one of my main criticisms of Hayek's book «The Fatal Conceit». It is simply erroneous to use the concept of «natural selection» in its biological sense to describe human action and human society. Natural selection in biology is based on competition, but natural selection, if we are even to use this term, in the human realm is however based on cooperation, which of course is voluntary. Cooperation can never be based on force or coercion.

102 Huerta de Soto (2010), p. 28.

103 Benson (1990), p. 32. 
written with the conception of the legal institution as evolutionary. ${ }^{104}$ Indeed, Hayek has shown that law making is a discovery process, and

if Hayek is correct that law-making is a discovery process similar to the discovery process of economics, it follows that the optimal system for provision of legal services should be predicated on a competition-based, rather than a monopoly based, system [...] Just as competition enables discovery and innovation in markets, competition enables discovery and innovation in law too. ${ }^{105}$

If we are to accept what Hayek convincingly argues, that the market for law is like other markets, then the problem of economic calculation (or knowledge) is very much applicable. The more centrally controlled any market is, the more difficult economic calculation, and hence rational action, will be. Like any market then, a higher degree of decentralization and freedom is what is needed.

The purpose of this paper was to take Mises' sharp observation on the need for individual secession in order for the liberal program for peace and prosperity to be realized, and to remove the doubts that he voiced regarding the feasibility of his own proposal. I believe I have done this by explicating the theoretical foundation of the concept of extraterritoriality, as well as showing how it has been applied historically and how extra-, or non-, territoriality is the only system which is consistent with individual rights, private property, and the non-aggression principle.

The concept put forth in this paper represents the highest amount of decentralization and the closest approximation to the voluntary market order regarding the legal institution that at least $I$ am capable of imagining. Our proposed system of nonterritoriality would allow for both an increasing diversification of law codes fully consistent with people's subjective wishes

\footnotetext{
104 Hayek (1982).

105 Stringham (2011), p. 26.
} 
as well as a unification of law. ${ }^{106}$ By allowing for individual secession our proposal represents a highly decentralized, dynamically efficient, competitive, voluntary and constantly evolving system, and combining our investigations with Hayek's and Benson's writings on the subject might in the end prove to be highly fruitful.

In the meantime we might simply entertain the idea that perhaps one day, in the not too distant future, it will again be perfectly normal to greet a stranger you meet on the street with the phrase «Sub qua lege vivis?»; according to what law are you living.

\section{BIBLIOGRAPHICAL REFERENCES}

Anderson, T. and Hill, P.J. (1977): "An American Experiment in Anarcho-Capitalism: The Not So Wild, Wild West» Journal of Libertarian Studies, pp. 9-29.

Bartolus (1914): On the Conflict of Laws, Cambridge, Harvard University Press.

BENSON, B.L. (1990): The Enterprise of Law: Justice without the State, San Francisco, Ca., Pacific Research Institute for Public Policy.

Block, W. (2011): «Evictionism is Libertarian; Departurism is Not: Critical Comment on Parr», Libertarian Papers, n.․․ 3.

Boldrin, M. and Levine, D.K. (2008): Against Intellectual Monopoly, London, Cambridge University Press.

CASEY, G. (2010): «Reflections on Legal Polycentrism», Journal of Libertarian Studies, pp. 22-34.

Cave, R.C. and Coulson, H.H. (1936): A Source Book for Medieval Economic History, Milwaukee, The Bruce Publishing Co.

Dollinger, Ph. (1999): German Hansa: The Rise of International Business 1200-1800, Routledge.

FreY, B. (2001): "Government Without Territorial Monopoly», The Independent Review VI, n. ${ }^{1}$, pp. 99-112.

\footnotetext{
106 Hoppe (2003).
} 
Friedman, D. (1973): The Machinery of Freedom: Guide to Radical Capitalism, Open Court Publishing Co.

Gordon, D., ed. (1998): Secession, State and Liberty, New Brunswick, New Jersey, Transaction Publishers.

HAYEK, F.A. (1982): Law, Legislation and Liberty, London, Routledge.

- (1988): The Fatal Conceit: The Errors of Socialism, London, Routledge.

Heller, M. (1998): «The Tragedy of the anti-Commons», Harvard Law Review.

Hoppe, H.H. (1988): A Theory of Socialism and Capitalism, Las Vegas, University of Nevada.

- (2000): Democracy: The God That Failed, New Brunswick, Transaction Publishers.

- (2003) ed.: The Myth of National Defense, Auburn, Al., Ludwig von Mises Institute.

HuerTA De Soto, J. (2010): Socialism, Economic Calculation and Entrepreneurship, Edward Elgar Publishing.

JoHnson, R.C.B. (n.d.): «Non-Territorial Governance, Mankind's Forgotten Legacy.», http:/ / www.panarchy.org/johnsson/ review.2005.html (accessed August 09, 2012).

Karsten, F. and Beckman, K. (2011): «Beyond Democracy», selfpublished.

Kinsella, S. (2008): Against Intellectual Property, Auburn, Al., Ludwig von Mises Institute.

LeFevre, R. (1966): The Philosophy of Ownership, Auburn, Al., Ludwig von Mises Institute (2007).

Liu, S.S. (1925): Extraterritoriality - Its Rise and Its Decline, New York, Columbia University.

LONG, R. (2002): «Privatization, Viking Style: Model or Misfortune?», http:/ / www.lewrockwell.com/orig3/long1.html (accessed August 09, 2012).

Mises, L. von (1921): «Economic Calculation in the Socialist Commonwealth», Collectivist Economic Planning, London, Routledge, pp. 87-130.

- (1949): Human Action, San Francisco, Fox \& Wilkes (1996).

- (1927): Liberalism, New York, The Foundation of Economic Education (1985). 
- (1919): Nation, State and Economy, Institute for Humane Studies (1983).

- (1922): Socialism, New Haven, Yale University Press (1962).

- (1962): «The Ultimate Foundation of Economic Science», Princeston, New Jersey, D. Van Nostrand Company, Inc.

Molinari, G. de (1849): The Production of Security, Auburn, Al., Ludwig von Mises Institute (2009).

Nock, A.J. (1943): Memoirs of a Superfluous Man, Auburn, Al., Ludwig von Mises Institute (2007)

Powell, J.B. (1925): «Extra-territoriality», China Weekly Review, June, pp. 9-11.

Pulsano, Ph., Wolf, K., Acker, A., and Fry, D. (1993): Medieval Scandinavia: An encyclopaedia, Taylor \& Francis.

RAND, A. (1966): Capitalism: The Unknown Ideal, New American Library.

Rothbard, M. (1973): For a New Liberty, Auburn, Al., Ludwig von Mises Institute (2006).

- (1982): Ethics of Liberty, New York, New York University Press (1998).

- (1981): «The Laissez-Faire Radical: A Quest for the Historical Mises», Journal of Libertarian Studies, n.. 3, pp. 237-253.

RunOLFSSON, B.T. (n.d.): «Ordered Anarchy: Evolution of the Decentralized Legal Order in the Icelandic Commonwealth», https://notendur.hi.is/ bthru/iep.htm (accessed September 02, 2012).

SAMUelsson, P.O. (n.d.): «Mises om Anarkism», Nattoäktaren, http://www.nattvakt.com/nnv/110318misesomanarkism. htm (accessed August 9, 2012).

SCHAFFeR, B. (2009): The Boundaries of Order: Private Property as a Social Order, Auburn, Al., Ludwig von Mises Institute.

Schumpeter, J.A. (1942): Capitalism, Socialism and Democracy, Taylor \& Francis (2003).

ScotT, S.P. trans. (1910): The Visigothic Code, Boston, Boston Book Company.

Smith, A.T. (1989): Time and Public Policy, University of Tennessee Press.

StRingham, E. and Zywicky, T.J. (2011): Hayekian Anarchism, George Mason University. 
TANNEHILL, L. and MoRRis (1970): The Market for Liberty, San Francisco, Fox \& Wilkes (1993).

Weber, M. (1919): «Politics as a vocation», From Max Weber: Essays in Sociology, New York, Oxford University Press (1946), pp. 77-128.

Whiston, Th. (2002): «Medieval Iceland and the Absence of Government», http://www.mises.org/daily/1121 (accessed September 02, 2012). 